\title{
Resolving Civil Wars before They Start: The UN Security Council and Conflict Prevention in Self-Determination Disputes
}

\author{
KYLE BEARDSLEY, DAVID E. CUNNINGHAM AND PETER B. WHITE*
}

\begin{abstract}
A large literature has demonstrated that international action can promote the resolution of civil wars. However, international actors do not wait until violence starts to seek to manage conflicts. This article considers the ways in which the United Nations Security Council (UNSC) reduces the propensity for self-determination movements to escalate to civil war, through actions that directly pertain to the disputing actors or that indirectly shape actor incentives. It examines the relationship between the content of UNSC resolutions in all self-determination disputes from 1960 to 2005 and the onset of armed conflict in the disputes. The study finds that diplomatic actions that directly address disputes reduce the likelihood of armed conflict, and that military force and sanctions have more indirect preventive effects.
\end{abstract}

Over the last several decades, international actors - often working through international organizations such as the United Nations (UN) - have focused increasing attention on managing violent intrastate conflict. This trend accelerated after the end of the Cold War, as efforts at the UN and other international bodies were then not stymied by superpower competition. Former UN Secretary-General Boutros-Ghali's Agenda for Peace (1992) emphasizes four areas of action that the international community could and should undertake to promote peace: preventive diplomacy, peacemaking, peacekeeping and post-conflict peace building. A large body of literature has examined the effect of the latter three types of action, and many of the conclusions reached have been optimistic. Studies have concluded that the UN can be effective at building peace, ${ }^{1}$ that peacekeeping works, ${ }^{2}$ that mediation can help facilitate settlement ${ }^{3}$ and that legal dispute resolution is especially effective. ${ }^{4}$

While this literature has advanced academic understanding of the effect of international actions and has had implications for policy makers seeking to resolve violent conflicts, there is still a substantial gap in our understanding of international efforts to prevent violent intrastate conflicts. Virtually all existing work focuses on managing or resolving ongoing violent conflicts.

\footnotetext{
* Duke University (email: kyle.beardsley@duke.edu); University of Maryland, Peace Research Institute Oslo (email: dacunnin@umd.edu); University of Maryland (email: pbwhite@umd.edu). Authors are listed in alphabetical order; equal authorship is implied. The data collection for this project was funded through a grant from the Folke Bernadotte Academy. The authors would like to thank Andrea Ruggeri, Lee Seymour, Megan Shannon and Jacob Kathman for their feedback, as well as participants in workshops at the University of Amsterdam, University of Essex and the Folke Bernadotte Academy. An earlier draft of this article was also presented in 2013 at the Annual Meeting of the American Political Science Association. Data replication sets are available at http:// dataverse.harvard.edu/dataverse/BJPolS and online appendices are available at http://dx.doi.org/doi:10.1017/ S0007123415000307.

${ }^{1}$ E.g., Doyle and Sambanis 2000.

2 E.g., Fortna 2008; Hultman, Kathman, and Shannon 2013.

3 E.g., Bercovitch and Gartner 2008; Regan and Aydin 2006.

4 E.g., Gent and Shannon 2010. The tenor of optimism is not universal, especially in earlier work (see, for example, Diehl, Reifschneider, and Hensel 1996).
} 
Yet international actors do not wait until violence starts to seek to resolve conflicts within countries. Rather, substantial effort is devoted to preventing the outbreak of violence, such as the preventive deployment of UN peacekeepers to Macedonia in 1992. We know little about whether these preventive efforts are effective.

This gap in our knowledge likely stems from the difficulty of identifying cases of the successful prevention of violent conflict. In studies of conflict termination, scholars can examine all armed conflicts and see which were ended through an implemented peace agreement and which were not. In conflict prevention, however, it is difficult to identify the set of potential civil wars - that is, intrastate disputes that had the potential to escalate to violence but did not.

In this article, we examine whether UN action influences the onset of violent civil conflict. We do so by examining the effect of UN action in all intrastate self-determination (SD) disputes from 1960 to 2005. SD disputes involve state governments and some ethnic groups seeking increased control over a particular territory in the state, which can include greater cultural, economic, or political autonomy up to a demand for secession to form an independent state or unite with another state. While SD disputes represent the most common cause of civil war in the last two decades, not all SD disputes lead to civil war. Indeed, from 1960 to 2005, the majority of SD disputes - including, for example, Puerto Ricans in the United States, Scots in the United Kingdom and ethnic Tatars in Russia - never escalated to armed conflict. ${ }^{5}$ Additionally, while all civil wars over SD stem from an SD dispute, such disputes can exist independently of and prior to (or after) violent conflict. Accordingly, we treat these disputes as a set of potential civil wars. In this article, we examine whether various types of resolutions adopted by the UN Security Council (UNSC) - including condemnations, diplomatic measures, and authorizations of sanctions and force - affect the likelihood that these disputes will become civil wars. We find that UNSC resolutions can have a substantial preventive effect, through both directly engaging the disputing parties and indirectly shaping their incentives.

\section{CIVIL WAR IN SELF-DETERMINATION DISPUTES}

We begin by presenting a brief theoretical discussion of the process leading to civil war in SD disputes. Civil wars are violent conflicts between a state and one or more organized non-state actors that reach some threshold of violence. They are typically either fought over control of the central government or some piece of territory in the state. In this article, we focus on SD disputes, so we only examine territorial incompatibilities.

SD disputes are the most common cause of civil war, but they are not the only cause. Indeed, several recent prominent civil wars, such as the wars in Syria, Afghanistan and Iraq, involve disputes over government. We focus on SD disputes because they provide a clear set of intrastate conflicts with the potential to become violent, but with variation among and within them over whether and when violence breaks out. As such, we can examine the potential for UNSC action to affect the likelihood of the onset of civil war. We expect, however, that this would also apply to disputes over government, as UNSC action would also have the potential to affect the decision making of states and dissidents in center-seeking civil wars. We return to a discussion of the potential differences between territorial and governmental civil wars in the conclusion.

Why do some SD disputes become civil wars and others do not? In general, disputes become civil wars when dissidents decide to use violence against state forces to pursue their aims. This focus on dissidents does not mean that states are rarely culpable; however, when states use

${ }^{5}$ Cunningham 2013, 659. 
violent repression, this is treated as a different phenomenon (such as one-sided violence or, at the extreme, genocide) unless dissidents respond with violence. ${ }^{6}$

There are three main factors that affect whether dissidents choose to use violence against the state to pursue their aims. First, dissidents must perceive some potential benefit of doing so. The clearest way in which dissidents may benefit from violent rebellion is by winning the conflict. Through victory, rebels have the chance to impose their ideal outcome, which in a civil war stemming from an SD dispute could be the full secession of the territory in dispute. ${ }^{7}$ Outright rebel victory in territorial conflicts, however, is extremely rare, and it is unlikely that many dissidents believe they can win the conflict. Yet even if they cannot win conflicts by defeating the government on the battlefield, dissidents can benefit from targeting violence against state forces if states grant concessions to them in return for an end to the conflict. In SD disputes, this often involves the state granting the SD group some degree of autonomy or control in the territory in which it is based. Negotiated outcomes are much more common than military victory by rebels, and are part of the process by which the rebels' concerns and grievances are addressed.

Rebel groups can also perceive a benefit from fighting if it provides them with the ability to extract resources - natural resources and/or resources from local communities and economic actors - in areas they control. ${ }^{8}$ These resources could include recruiting more support against the state. More broadly, the 'outbidding' logic in the terrorism literature suggests dissidents may have incentives to escalate to violent activity to gain politically within the constituent group by demonstrating their commitment to the cause. ${ }^{9}$

A second variable that affects dissidents' decisions to violently engage the state is the anticipated costs of doing so. Violent conflict is costly, as dissidents face the potential for violent repression and must exhaust resources in armed struggle. ${ }^{10}$ Additionally, much of the fighting in SD disputes generally takes place in the territory under dispute, and destruction of this territory is costly for dissidents. Pertinent to costs, state strength is a key determinant of civil war onset. ${ }^{11}$ States vary dramatically in their ability to impose costs on dissidents. In some cases, the state is so weak that rebels can operate largely outside of its coercive reach particularly in peripheral areas. In others, states are so strong that they can effectively repress violence throughout their territory by imposing large costs on dissidents.

The third factor that affects dissident decisions about whether to violently rebel is whether they and the government are able to reach compromises to avoid civil war when they recognize compromise to be mutually preferable to war. Reaching settlements can be difficult because of potential barriers to bargaining. ${ }^{12}$ Foremost, states and dissidents may be unable to reach compromise settlements that avert civil war if they do not agree on the likely course of that war. If states underestimate (or if dissidents overestimate) how costly conflicts will be for states, then the state may offer insufficient concessions, and civil wars may emerge as a consequence of the bargaining failure.

${ }^{6}$ For a discussion of the interaction of dissident protest and state repression - short of civil war - see, for example, Francisco (1995), Lichbach (1998) and Moore (1998).

7 In center-seeking civil wars, rebel victory would involve the complete overthrow of the government.

8 Collier and Hoeffler 2004.

${ }^{9}$ Kydd and Walter 2006.

10 Opportunity costs also shape dissidents' incentives, as fighting often precludes their ability to pursue demands via more legitimate political channels. The opportunity costs of fighting are low when the parties expect that their chances of achieving their aims via the legitimate political process are slim.

11 Fearon and Laitin 2003.

12 This discussion of bargaining draws heavily on the bargaining approach to war, summarized most clearly in Fearon (1995). For a discussion of bargaining approaches to civil war, see Walter (2009). 
States and dissidents may also be unable to settle disputes if one or both sides cannot commit to abide by the terms of an agreement reached. If, for example, a state promises an SD group greater control over its own affairs, but the group does not believe that the state will follow through on that promise - especially if the group is vulnerable to prosecution or coercion and when high levels of mistrust persist - then dissidents within the group may choose to rebel. These commitment problems can lead to civil war even if states and dissidents have similar perceptions about the likely costs and outcome of the conflict. A related issue is that the parties may perceive an issue to be indivisible. In some cases - such as Kashmir or Jerusalem - the territory has strong symbolic importance for each side and so the actors may perceive the issue in all-or-nothing terms. ${ }^{13}$

\section{UNSC RESOLUTIONS AND CIVIL WARS OVER SELF-DETERMINATION}

International actions, including those by the UNSC, can address these underlying causes of civil war and impact the likelihood of civil war. The UNSC is quite active in SD conflicts, and has passed a significant number of resolutions related to these disputes. The focus here is on conflict prevention. In general, UNSC preventive actions fall into four broad categories. First, the UN engages in diplomatic engagement - including good offices, mediation, fact-finding, civilian monitoring missions and the formation of special tribunals. For example, UNSC Resolution 367 of March 1975 called on the UN secretary-general to undertake a mediation role in the dispute over the status of Turkish Cypriots. Secondly, the UNSC authorizes the deployment of force, which can either include UN peacekeeping missions - such as the UN Observer Mission in Georgia established by Resolution 858 in August 1993 to supervise a ceasefire between the Georgian government and Abkhaz separatists - or authorizations of non-UN multinational forces - such as the NATO-led International Security Assistance Force in Afghanistan, which was authorized by Resolution 1386 in December 2001, and which, inter alia, affected the Uzbek and Tajik SD movements. ${ }^{14}$ Thirdly, the UN levies sanctions on countries, and UNSC resolutions can impose, reauthorize or expand sanctions on the country involved. An example of this type of UNSC activity is Resolution 713, which established an embargo in September 1991 on military materiel being exported to the former Yugoslavia, where a number of SD disputes had escalated or were at risk of escalating to violence. Fourthly, and more passively, UNSC resolutions often contain condemnations, in which the Security Council deplores hostilities, non-compliance with prior UN directives or international agreements, or human rights violations. This last category includes Resolution 1076, issued in October 1996, which condemned the civil war in Afghanistan - a conflict that incorporated the Tajik and Uzbek SD struggles.

These types of actions related to UNSC resolutions have the potential to prevent SD disputes from escalating to full-blown civil war via different mechanisms. Broadly, UNSC resolutions either through the resolution itself or through the actions that a resolution authorizes - are able to do this by increasing the costs of conflict for the combatants, decreasing the benefits of fighting (the opportunity costs of peace) or otherwise alleviating the barriers to bargaining.

13 E.g., Toft 2006. Powell (2006) argues that such indivisibility issues can be considered as special cases of a more fundamental commitment problem in that the parties could bargain over the probabilities assigned to a lottery that decides the fate of the issue but neither side can credibly commit to adhere to the lottery results.

14 While resolutions authorizing the deployment of peacekeepers or other forces may not specifically authorize 'force' as an action - and indeed may operate under Chapter 6 of the UN Charter, which explicitly pertains to the 'pacific settlement of disputes' - we consider 'force' to involve the deployment of military or police forces, not necessarily the use of violence. 


\section{Shaping the Cost-Benefit Calculus}

We argue that the UN can contribute to violent conflict prevention by increasing the costs or decreasing the benefits of fighting. We consider the increasing of costs and the decreasing of benefits of fighting as a single mechanism by which the UNSC can affect the incentives of the state and SD group to escalate to armed conflict, and argue that movements in the costs-benefits ratio of either side in a negative direction will make armed conflict less likely, as long as the other side's ratio does not move in a positive direction. ${ }^{15}$ This relates to Karreth and Tir's finding that state membership in a 'portfolio' of highly structured intergovernmental organizations (HSIGOs) can decrease the propensity of low-level intrastate armed conflicts to escalate to a high level of violence by increasing the costs of armed conflict. ${ }^{16}$ However, here we focus on whether intrastate disputes turn violent in the first place or remain relatively pacific. Rather than examine overall intergovernmental organization (IGO) membership, we focus on the specific tools that the UNSC has at its disposal that could be used to manipulate the costs and benefits of fighting, the most relevant of which are authorizations of force and sanctions. We also consider how diplomatic engagements can shape the opportunity costs of fighting. We take up each of these in turn.

Having troops on the ground can directly raise the potential costs of fighting for both sides by enforcing the peace - by punishing and exposing violators, 'inter-positioning' peacekeepers between potential combatants or otherwise making violence more difficult - or increasing the likelihood that further international action will be taken in the face of continued violence. ${ }^{17}$ The costs of violence increase if a peacekeeping mission or an authorized multinational force might engage the combatants. Moreover, even the presence of military monitors can make attacks more costly if the monitors can determine culpability for the violence - which can trigger reprisals by international or domestic actors - and/or serve as an early-warning mechanism that reduces the potential for the parties to catch one another off guard. Military missions can also decrease the benefits of victory, as the victorious party will only have limited de facto sovereignty with international forces in place.

An example of UNSC resolutions that authorize force moving cost-benefit calculations in favor of peace is the preventive deployment of UN peacekeepers to Macedonia at the height of the war in Bosnia and Herzegovina in 1992. With UNSC Resolution 795, for the first time, UN peacekeepers were deployed not in response to an ongoing conflict but to forestall a dispute from escalating to violence. There was a high probability of civil war occurring in Macedonia, given the SD dispute between Albanians and Macedonians in the country and the ongoing ethnic violence in the other former Yugoslav states. Hundreds of peacekeepers were deployed along the border areas of Macedonia and into the interior, which served to raise the costs of violence by blocking the flow of fighters and weapons from other parts of the former Yugoslavia. Ultimately, UN intervention there was instrumental in preventing the Albanian SD dispute in Macedonia from escalating to armed conflict. ${ }^{18}$

Sanctions also impose immediate costs on the parties involved, particularly the government. There is some doubt in the literature as to the efficacy of international sanctions in compelling

15 In a sense, we assume a lumpy bargaining space, such that increases in costs relative to the benefits increases the likelihood that the actors will find some agreement that is mutually preferable to war.

16 Karreth and Tir 2013.

17 Hultman, Kathman, and Shannon 2013. Also, while Sambanis (1999) and Greig and Diehl (2005) contend that peacekeeping can have a negative effect on parties' ability to resolve the underlying dispute behind a conflict, we examine here the ability of the UNSC to prevent such disputes from escalating to violence, not the resolution of the underlying grievances.

18 Ackerman and Pala 1996. 
policy change, ${ }^{19}$ and Drezner finds that the most effective sanctions are those that are threatened, but never implemented. ${ }^{20}$ However, other findings emphasize that sanctions can be quite effective when combined with other policies, ${ }^{21}$ and can significantly destabilize target governments. ${ }^{22}$ We posit that in the context of an SD dispute, sanctions can directly impact a party's warfighting capacity by putting an embargo on the importation of fuel or military materiel, such as in the case of the 1992 arms embargo levied against Yugoslavia during the war in Bosnia and Herzegovina (Resolution 713). Further, sanctions could also more broadly damage a state's economy - as in the case of the sanctions against Taliban-ruled Afghanistan in 1999 (Resolution 1267). While in some cases general repression may increase with economic sanctions ${ }^{23}$ in the context of SD disputes that involve a risk of civil war, both economic and military sanctions should make the use of military force relatively more expensive, given import or financial restrictions and the potential broader economic damage. This will make the government warier of engaging in repression that could lead to a military conflict. Further, sanctions also help induce the parties to settle, because lifting them is an incentive to agree on a compromise settlement. That is, sanctions can increase both the direct costs and the opportunity costs of fighting. In addition to altering the costs of conflict, sanctions can also affect the benefits of winning. Imposing sanctions on the government for, say, violations of international law or human rights abuses, might signal to the dissidents that the UNSC is willing to act against such activities and thereby reduce the prospects for the dissidents to pursue a heavyhanded consolidation of power after victory. Sanctions imposed on the government, then, could potentially decrease dissidents' expectations of the benefits of military victory and make them more open to compromise.

The UNSC also has other means of shifting the cost-benefit calculus by raising the palatability of concessions and thus increasing the opportunity costs of fighting. Diplomatic action in particular can reduce the domestic political incentives that leaders may have to resort to violence against SD movements - reducing the audience costs that leaders pay if they are perceived to have backed down in a dispute. The mediation literature has noted that third-party involvement can serve to dilute the leader's responsibility for making unpopular concessions, and provide signals to the domestic audience that concessions are worthwhile. ${ }^{24}$ Indeed, this may have been the case in 1997 when the leadership of Greek Cyprus began installing missile batteries that had the potential to reignite the unresolved Turkish Cypriot SD dispute. UNSC resolutions $(1117,1146$ and 1217$)$ in response to the missiles seem to have provided political cover to the Greek Cypriot leadership, which had campaigned for election on the platform of installing the missiles. ${ }^{25}$ The resolutions implicitly condemned the Turkish Cypriots for allowing 35,000 troops from Turkey onto the island in addition to deploring the 'introduction of sophisticated weaponry'. Concurrently, the resolutions also encouraged mediation activity by the secretary-general of the UN and the pursuit of 'bi-communal' connections on the island. This was coupled with aggressive shuttle diplomacy by a special UN envoy to Cyprus at the height of the crisis. ${ }^{26}$ Along with other international pressures, the resolutions and the

19 E.g., Pape 1997.

20 Drezner 2003.

${ }^{21}$ E.g., Elliot 1998.

${ }^{22}$ E.g., Marinov 2005

${ }^{23}$ E.g., Escriba-Folch 2012; Wood 2008.

${ }^{24}$ E.g., Beardsley and Lo 2013.

25 Reuters, 'EU Talks Seen behind Cyprus Missiles Move', 29 December 1998 (accessed 30 June 2013).

${ }^{26}$ AFP, 'UN Envoy Launches New Round of Cyprus Shuttle Diplomacy', 16 October 1998 (accessed 30 June 2013). 
diplomatic activity they authorized are believed to have contributed to the ultimate resolution of the crisis. $^{27}$

\section{Reducing Barriers to Peaceful Settlement}

In addition to shaping the costs and benefits of fighting, the UNSC can mandate and support activities that improve the ability of dissidents and governments to reach an agreement or avoid war. By reducing uncertainty regarding what each side would be willing to accept in a compromise settlement and improving the prospects that the sides will commit credibly to a settlement, the UN can improve the ability of states and SD groups to identify and settle on alternatives that are mutually preferable to fighting.

UNSC resolutions can help ameliorate problems related to uncertainty through diplomatic action. Mediation, good offices, fact-finding missions and other diplomatic efforts can help disputants become more realistic about each others' capabilities and resolve. ${ }^{28}$ Although it might be difficult for the UN to access and communicate new information that the parties themselves do not already have, ${ }^{29}$ the diplomatic process, and its avenues of communication and investigation, can improve transparency among the actors. The dialogue that mediation and good offices typically fosters can reinforce more legitimate, peaceful mechanisms by which dissident groups can air grievances against the state, and in which learning about each side can take place.

Turning to the problem of credible commitments, the authorization of peacekeepers or observers can help reduce fears that parties will fail to implement any settlements that are reached. Scholars who study the effect of peacekeeping and observer missions on conflict termination ${ }^{30}$ have shown that these missions can help enforce settlement implementation and thereby improve the prospects for settlement in the first place. According to Walter, third-party enforcement is a crucial mechanism to help resolve this 'critical barrier' to civil war settlement. $^{31}$

\section{Cheap Talk}

It is less clear whether resolutions with simple condemnations of the disputants can have a strong effect. On the one hand, condemnations do not commit the UN or member states to any tangible action and may simply be cheap talk. For example, many condemnations have been issued against Israel - such as those calling on Israel to cease efforts to incorporate East Jerusalem after the June 1967 war (for example, Resolution 252), but the UNSC has rarely taken tangible action to shape Israel's relationship with the Palestinian Arabs in the occupied territories. Indeed, the lack of tangible action confirms in the eyes of the relevant actors that condemnations can in fact be treated as cheap talk.

On the other hand, resolutions containing condemnations may serve to directly increase the potential costs of civil war because agreement by the permanent-five members of the UNSC (P-5) five powerful states with disparate preferences $^{32}-$ is required for a UNSC resolution to pass.

27 Middle East Review World of Information. 1999. 'Cyprus-review', 1 July (accessed 30 June 2013).

28 E.g., DeRouen and Möller 2013; Gartner 2011; Kydd 2003, 2006; Quinn et al. 2013; Regan and Aydin 2006.

${ }^{29}$ Fey and Ramsay 2010; Smith and Stam 2003.

30 E.g., Fortna 2004, 2008.

31 Walter 2002.

32 The importance of preference divergence has been noted by Voeten (2005), Thompson (2009) and Chapman (2009), who find that UNSC resolutions serve an informational role precisely because they are so hard to pass. 
A condemnation in such a resolution is a clearer signal to governments (and potentially dissidents) that the UN is committed to imposing costs on them in the event of violence than a condemnation by a single state or even the UN General Assembly. Parties are put on notice that the UNSC is monitoring their dispute closely and may impose more direct costs in the event of violence. In light of this discussion, we lack firm priors on the expected effects of condemnations found in UNSC resolutions.

\section{The Potential for Moral Hazard}

In considering the preventive functions that UNSC actions can serve, it is also important to consider the potential for a moral hazard problem to present a countervailing tendency. While we expect that UNSC resolutions will on average work to decrease the likelihood of civil war, it is also possible that in some cases these resolutions will actually make civil war more likely. When UNSC resolutions are perceived by one side in an SD dispute to be supportive of its objectives, the expectation of UN support can decrease that actor's expected costs of civil war and increase its prospects for victory, thereby decreasing the attractiveness of a negotiated outcome. Put differently, according to this logic, the expectation of UN support may inspire more aggressive behavior by one of the disputants. ${ }^{33}$ If there are many cases in which UNSC action increases the likelihood of civil war, then it will make it less likely that we will find evidence of the preventive effect of resolutions.

The UNSC almost certainly considers the potential for moral hazard as it decides how to act in each case. If this is an active consideration, then we should only expect $\mathrm{UN}$ action to increase the propensity for civil war when it has strong incentives to act contrary to a spirit of neutrality and bolster the prospects of success for one of the parties - such as when the other party poses a broader threat to international stability or has seriously run afoul of international law - or when the potential for moral hazard is not easily foreseen. While the former certainly occurs, ${ }^{34}$ it requires a non-trivial amount of consensus among the UNSC members to bolster one of the sides, such that it is not likely to be so common and powerful that it dominates the relationship between UN actions and civil war prevention. As for the latter, we might expect the potential for such instances of moral hazard to be both rare and stochastic.

\section{Direct vs. Indirect Engagement}

We consider how the patterns of behavior in SD disputes respond to UNSC resolutions that directly address the dispute at hand as well as those that occur in more of a regional context with only indirect relevance. That is, in a number of cases, the UNSC takes actions that are not directly designed to manage SD disputes, but that can still affect the degree to which states and dissidents see civil war as a viable option. For example, UNSC resolutions that authorized force and sanctions against combatants during the Second Congo War (1998-2003) were relevant to the Bakongo and Lunda/Yeke SD movements, but only indirectly - even though the two SD groups were not referenced in the resolutions, the scope of the resolutions (and the conflict to which they applied) were simply so big that they could not avoid shaping the incentive structures of other relevant political actors in the Democratic Republic of Congo during this time, including peripheral SD movements. When acting in contexts that have indirect implications for SD movements, UNSC resolutions - specifically those that authorize sanctions

\footnotetext{
33 This dilemma is noted in the literature as a potential drawback to the UN's more aggressive stance on humanitarian intervention after the Cold War (e.g., Kuperman 2005; Rauchhaus 2009).

${ }^{34}$ Benson and Kathman 2014.
} 
or force, as explained below - can have deterrent effects by reducing the propensity for SD disputes to escalate to civil war. These indirect effects may in some cases be unanticipated by the UNSC, but we suspect that in many cases they are anticipated by the resolution authors. Although we expect that indirectly pertinent UNSC resolutions can have conflict-preventive effects just as directly pertinent ones can, we consider their effects separately because of the potential uncertainty in whether the effects of such resolutions are foreseen and/or intended, as well as the heterogeneous contexts in which direct and indirect UNSC resolutions are adopted.

Of the types of action considered above to have direct effects, we argue that the authorization of force and sanctions is the most likely to have indirect effects because they involve tangible manipulation of the cost-benefit calculations with a clear potential for downstream consequences. It is more difficult to consider how diplomatic engagement would significantly change the incentives within a dissident-government relationship that is only indirectly related to the resolution. Moreover, condemnations will have a tough enough time overcoming the cheap talk problem when the resolutions directly name the responsible actors in an SD dispute that we do not expect condemnations to significantly affect actors that are only obliquely implied.

UNSC authorizations of force can have an indirect negative impact on the likelihood that a given SD dispute will escalate to civil war because the pacifying effect of peacekeepers should not be strictly limited to the conflict that drew them to a country or region in the first place. Rather, the presence of peacekeepers in a given country decreases the likelihood of conflict escalation or recurrence wherever the peacekeepers are in a position to observe or prevent escalatory behavior. ${ }^{35}$ While mandates may provide strict rules of engagement and limits on the activity of peacekeepers, their presence and actions should have positive externalities to any dispute that is realistically within their reach. ${ }^{36}$ For example, the stationing of peacekeepers in Kurdish territories along the border at the close of the Iran-Iraq War (Resolution 619) can be understood to have indirectly reduced the probability that the Kurdish SD disputes in both countries would escalate to civil war. At the very least, the presence of international observers should make it harder for both potential rebels and the government to 'get away with' acts of violence. As another example, the deployment of UN peacekeepers in 1990 to post-civil war Nicaragua (Resolutions 650 and 653) destroyed thousands of former rebel weapons - including those of indigenous fighters. ${ }^{37}$ This action would have made it more difficult for the subsequent indigenous SD dispute later that decade to escalate to civil war.

Sanctions directed at a state, even if they are not imposed because of a specific SD dispute, should also impact the likelihood that an indirectly related SD dispute in that country will escalate to armed conflict. Anything that impacts the state's ability to repress or fight a civil war should affect all potential civil wars in a country, given the fungibility of the resources necessary for repression. For example, sanctions directed against general apartheid activities in South Africa (for example, Resolutions 418 and 591) increased the costs of state violence against any domestic opposition group, including indirectly related SD groups such as the Khoisan and Zulus. Moreover, the authorization of sanctions against a state in one context is a credible signal that the UNSC is sufficiently motivated to use this tool to address a security concern in that state, and government and dissident actors in an indirectly related SD dispute are likely to update their expectations to anticipate being the target of additional sanctions if they

35 This argument is in line with expectations of the literature on peacekeeping (e.g., Fortna 2004, 2008).

36 Related, Beardsley (2011) finds that peacekeeping prevents the spread of conflict across state borders, and Beardsley and Gleditsch (2015) find that conflict zones are less mobile in countries with peacekeeping deployments.

37 Minorities at Risk 2009. 
TABLE 1 Regional Distribution of SD Movements and Civil Wars

\begin{tabular}{lccc}
\hline \hline Region & $\begin{array}{c}\text { Number of SD } \\
\text { disputes }\end{array}$ & $\begin{array}{c}\text { Percent of total SD } \\
\text { disputes }\end{array}$ & $\begin{array}{c}\text { Percent with civil } \\
\text { war }\end{array}$ \\
\hline North America & 5 & 3.52 & 0.00 \\
South/Latin America & 8 & 5.63 & 0.00 \\
Western Europe & 16 & 11.27 & 12.50 \\
Soviet Union (former) & 18 & 12.68 & 27.78 \\
Eastern Europe & 13 & 9.15 & 46.15 \\
Oceania & 2 & 1.41 & 50.00 \\
Sub-Saharan Africa & 32 & 22.54 & 53.13 \\
East Asia & 20 & 14.08 & 60.00 \\
South Asia & 21 & 14.79 & 61.90 \\
Middle East/North Africa & 7 & 4.93 & 85.71 \\
Total & 142 & 100 & 43.66 \\
\hline \hline
\end{tabular}

escalate their dispute to armed conflict. The demonstration of UNSC resolve to impose costs in one context can increase the potential for deterrence in related contexts.

\section{DATA AND METHODOLOGY}

To test whether UNSC resolutions decrease the likelihood of civil war, we use data from all years of an SD group's existence from 1960 to 2005. The population of SD movements comes from the Center for International Development and Conflict Management (CIDCM) Peace and Conflict Report. ${ }^{38}$ This report identifies 145 SD movements residing in seventy-seven countries that demand more SD - that is, increased local control and autonomy for an ethnic group in a given territory. ${ }^{39}$ This list encompasses both groups that have participated in civil war, such as the Kurds in Turkey and Iraq, and those, such as the East Caprivians in Namibia, that have not. The data reflect the resolution or emergence of SD disputes at different times between 1960 and 2005. For example, the Afrikaners (in South Africa) dispute only emerges in 1994 with the end of apartheid, whereas the Kosovar Albanian dispute exits the data after 1999 with de facto Kosovar independence. ${ }^{40} \mathrm{We}$ include a list of all SD groups in the Appendix, as well as an indication of whether the group experienced a civil war onset. Of the SD groups examined, 44 per cent experienced a civil war between 1960 and 2005. Table 1 shows the number and percentage of SD groups from each region as well as the percentage of groups in the region that experienced a civil war.

38 The CIDCM data (Marshall and Gurr 2003) stem from the Minorities at Risk data, which focus on 'politically active ethnic groups' (see Cunningham 2013), so 'SD movements' here exclude separatist movements without a clear ethnic dimension.

${ }^{39}$ We include 142 of these groups, since Cunningham (2013) was unable to find any organizations representing Indonesian Dayaks and Russian Avars for the entire period. Additionally, CIDCM includes Lebanese Palestinians as a group distinct from Israeli Palestinians, but Cunningham (2013) found no evidence of Palestinian groups in Lebanon advocating SD separately from the Israeli-Palestinian dispute.

40 While the emergence of groups such as the Afrikaners raises the possibility that the entry into the data of an SD group is endogenous to UNSC action, many of the SD movements in our data, such as the Scots in the UK or the Kurds in Iraq, exist prior to the modern era. Those that emerge within the time frame of our data often do so as the result of events exogenous to UNSC action, such as decolonization or the break-ups of the Soviet Union and Yugoslavia. 
Our unit of analysis is the state-SD group dyad year. The dependent variable is an indicator of whether a new armed conflict, as defined by the Uppsala Conflict Data Project/Peace Research Institute of Oslo Armed Conflict Dataset, ${ }^{41}$ began in that year. Armed conflict onsets are years when at least twenty-five battle-related fatalities occurred and in which there are at least two years of peace prior to the onset of hostilities. We use the twenty-five battle-deaths threshold instead of a higher threshold for two reasons. First, the mechanisms that we propose for the onset of intrastate armed conflict apply to both high and low levels of violence. To code the episodes of armed conflict with twenty-five to 1,000 battle deaths as periods of relative peace would miss important variations in the outcome of interest that we would like our model to explain. Secondly, we are interested in whether UNSC resolutions are able to proactively reduce the propensity for conflict, which would mean attenuating violence before a threshold like twenty-five battle-related fatalities. Efficacy at reducing the escalation to a much higher threshold without efficacy at lower levels of violence would imply a weaker - though still important - form of prevention that would be better characterized as reactive. In supplemental robustness checks, we find that the key findings at the lower threshold hold at the 1,000 battledeaths threshold, suggesting that the preventive effects we find are not only applicable to the conflicts that were unlikely to escalate to massive violence.

We use Cunningham's study of SD group fractionalization and the onset of armed conflict to tie the SD movements to specific armed conflicts. ${ }^{42}$ Our analyses drop the years in which there is an ongoing armed conflict, as well as the two years immediately following the end of an armed conflict. Some of the onsets are new armed conflicts, while others are recurrences. We conduct different analyses with different samples to assess whether UNSC resolutions help prevent the onset of new armed conflicts involving previously peaceful SD movements, the recurrence of armed conflict involving SD movements or both. One sample thus includes all groups at risk for conflict, and another sample includes just those that have yet to experience a civil war.

Using discrete binary time-series cross-sectional data, we run logit regressions that are essentially event-history models. ${ }^{43}$ To account for duration dependence, we follow Carter and Signorino and include a cubic polynomial of the time at risk. ${ }^{44}$ Since our analysis begins in 1960 , but many of the groups existed prior to that year, we would run into the problem of leftcensoring if we started the risk time for all groups at zero in $1960 .{ }^{45}$ So, for the thirty-four groups that already existed in 1960, we chose as their origin point the later of the following: (1) the year after any post-1946 armed-conflict episodes ended; (2) the entrance into the international system of the respective country or (3) $1946 .{ }^{46} \mathrm{We}$ report standard errors that are robust to clustering on the SD movement.

Our independent variables measure the content of recent UNSC resolutions related to the SD movement. Beardsley has coded information on the content of all the resolutions during the time period of our study, including which countries were the concern of the resolutions and the actions mandated in the operative paragraphs - condemnations, diplomacy, force or sanctions. ${ }^{47}$ After matching the resolutions to all the relevant countries with SD movements, we went

41 Gleditsch et al. 2002; Themner and Wallensteen 2012.

42 Cunningham 2013.

43 Beck, Katz, and Tucker 1998.

44 Carter and Signorino 2010.

45 Carter and Signorino 2013.

46 By not going back prior to 1946, we are assuming that the international system fundamentally changed in 1945 , with the end of WWII and the formation of the UN.

47 Beardsley 2013. 
through each resolution and determined whether the resolution directly pertained to the SD movement in question, indirectly pertained or was not relevant. ${ }^{48}$

In the analyses below, we examine whether different types of UNSC resolutions have different effects. We aggregate the various types of activities in the resolutions into the following categories: diplomacy, new force authorizations and mandate expansions, sanctions, force re-authorizations, condemnations and 'all else'. The categories are not mutually exclusive, except that the 'all else' category is true only if there is no activity of the other listed types. ${ }^{49}$ 'Diplomacy' includes UNSC instructions for the secretary-general to offer his good offices, mediate or investigate an issue; mandates that empower fact-finding or monitoring entities; calls for other actors to mediate; the formation of special courts; and mandates that call for UN entities to carry out peacebuilding activities - focused on strengthening political and economic institutions - including demobilization, disarmament and reintegration programs. Although some of these actions are distinct from each other, they share an emphasis on non-coercive UN involvement. Moreover, Boutros-Ghali's Agenda for Peace similarly combines these activities as part of 'preventive diplomacy'. 'Force' mandates include those pertaining to missions overseen by the UN Department of Peacekeeping Operations, as well as those carried out by multinational forces with explicit authorization from the UNSC. Mandates of 'new force' are separated from 'force reauthorizations' because, unlike other types of UN action, force authorizations carry an explicit expiration date that can only be extended with another resolution. Simple extensions of mandates to a later date are coded as their own category, and are generally considered to be involvement that is not nearly as active as resolutions that authorize or endorse new approaches. We include mandate expansions and all authorizations to use all necessary means as new force. 'Sanctions' are explicit demands and authorizations for the international community to restrict the trade, financial privileges, or movement of specific governments or leaders. Resolutions are coded for sanctions when they authorize new sanctions as well as when they call for the continuation or expansion of existing sanctions. Finally, 'condemnation' covers explicit statements in the operative paragraphs that deplore such actions as hostilities, human rights abuses and the failure to comply with existing agreements. We also include in this category explicit threats - but not the actual implementation - of sanctions or other punishments.

We then created two separate indicators for each type of action: one for the resolutions that directly pertained to the SD movement in question, and one for the resolutions that indirectly pertained. In most cases, resolutions were determined to directly pertain if the SD movement was explicitly mentioned. For example, Resolution 541 (1983) reads 'The Security Council [...] Deplores the declaration of the Turkish Cypriot authorities of the purported secession of part of the Republic of Cyprus' (emphasis added). The direct relevance to the Turkish Cypriot SD dispute is clear. However, many resolutions were determined to have direct relevance based on the context in which they were issued. The overarching decision rule for direct pertinence was whether the issuers of the resolution (the UNSC) and the targets (the government in question and the SD movement) would have understood the resolution to primarily pertain to them, even if they were not explicitly mentioned. Where that criterion was satisfied, the resolution was

48 The International Peace Institute (IPI) provides important data on 'Compliance with Security Council Resolutions' (Mikulaschek and Perry 2013). However, the IPI data only cover compliance of the parties in a dispute that has escalated to civil war. To examine the prevention of civil war, data on potential wars are needed, which is why we marry our UNSC resolution data to the Cunningham (2013) data on SD disputes.

${ }^{49}$ We drop the resolutions pertaining to admittance to the UN. The 'all else' category does not mean that such resolutions are without substance, but that the resolutions do not fit into the above categories. 'All else' includes many cases in which the UN issues a declaration of concern for a conflict but does not condemn it outright. 
coded as directly pertinent. For example, Resolution 383 (1975), which renewed the peacekeeping mandate of the UN mission in Cyprus and called for renewed peace talks between the 'two communities', was coded as pertaining to direct force, even though the 'Turkish Cypriots' are not explicitly mentioned. Given the context in which the resolution was passed, 'two communities' could only be understood as referring to Greek and Turkish Cypriots. Resolutions pertaining generally to Israeli incursions into southern Lebanon in the 1970s (for example, Resolution 425 in 1978) were understood to directly pertain to Palestinians living in Lebanon - even though they did not name 'Palestinians' - as the Israeli incursions were primarily directed against Palestinian militant groups.

Resolutions that did not meet the criteria for direct relevance - meaning that they did not explicitly mention or primarily pertain to the SD movement, but addressed a broader statewide or regional conflict to which the SD group was a plausible participant - were coded as indirectly relevant. For example, resolutions during the Congo crisis in 1960 that addressed the secessionist conflict in Katanga Province (for example, Resolutions 143 and 145) were coded as indirectly pertaining to the Lunda and Yeke SD movement, because this group was heavily represented in Katanga Province and was therefore a plausible participant in the Katanga conflict. The resolutions were not coded as being directly relevant to the Lunda and Yeke, because they were not explicitly mentioned in the resolutions, nor was the conflict specifically a manifestation of the Lunda and Yeke SD movement. The Katanga resolutions, meanwhile, were coded as being neither directly nor indirectly relevant to another Congolese SD group, the Bakongo. The Bakongo were concentrated far away from Katanga (in a country roughly the size of Western Europe) and were therefore not a plausible actor in the Katanga conflict.

In another example, broad condemnations of apartheid policies in South Africa (for example, Resolution 391, 1976) were coded as indirectly relevant to both the Zulu and Khoisan SD movements because the conflict over the apartheid system included the formation of Bantustan 'homelands' for these groups, making them potential participants in the anti-apartheid conflict. These resolutions were not directly relevant to these SD movements because the Khoisan/Zulu SD movements were not well integrated with the anti-apartheid social movements, and were thus not directly implied as pertinent to the UNSC resolutions against apartheid.

Also, resolutions that addressed an international conflict with inherent relevance to SD movements were coded as indirectly related. For example, the establishment of a peacekeeping mission in the Golan Heights (Resolution 350, 1973) was coded as indirectly related to the Palestinian SD movement in Israel, given the Palestinians' role in the broader Arab-Israeli conflict as potential combatants and as a galvanizing cause. In sum, if a resolution did not explicitly address an SD movement and could not be interpreted as being primarily addressed to that SD movement, but did address a broader state- or region-wide conflict to which the SD group was a plausible participant - regardless of their actual involvement - the resolution was coded as indirectly relevant.

Resolutions that did not fulfill the criteria for either direct or indirect relevance were classified as not relevant - even if they pertained to the country in which the SD movement resides. Resolution 164 (1961) provides a clear example. This resolution addressed French colonial policy in Tunisia, and accordingly was coded as having no relevance to the Basque and Corsican SD movements in metropolitan France.

Of the 142 SD movements at risk of armed conflict in our sample, nineteen had some directly pertinent UNSC resolution condemning the actors - nine had sanctions, twelve had new force authorizations, nine had re-authorizations, eleven had instructions for diplomacy and twentyone had resolutions in the 'all else' category. Twenty-five had some indirectly pertinent UNSC resolution condemning the actors - nineteen had sanctions, seventeen had new force 
authorizations, fifteen had re-authorizations, twenty-four had instructions for diplomacy and twenty-nine had resolutions in the 'all else' category. ${ }^{50}$

To measure the effect of recent UNSC resolutions, we use an exponential decay function. We posit that the effect of a resolution is likely to last much longer than a single year, but that the weight of its influence should decrease over time. Moreover, when multiple resolutions of the same type have been issued in the recent past, they should have a cumulative effect. Using a decay function allows us to capture these dynamics. We use a four-year half-life, in which a resolution has a weight of 1 in the year in which it was adopted, and the weight decreases each year such that it has a weight of 0.5 after four years, 0.25 after eight years, etc. ${ }^{51}$ As additional resolutions are adopted, they add a weight of 1 to the decaying measure, and a new decay function is applied to the weight of that resolution at its date of adoption. Multiple resolutions with the same actions in the same year are treated as having an initial weight equal to the number of resolutions. To avoid simultaneity bias, we lag all the independent variables by one year.

We perform separate regressions for each type of UNSC action while controlling for the combined weights of all the other types of action. The estimated coefficients on the actions variables should thus be interpreted as the effects of those actions while holding constant the general level of other UNSC involvement. In addition to controlling for the time at risk, we control for a number of variables that correlate with the ex ante fragility of peace. If UNSC involvement is fairly reactive and tends to go to the cases at greatest risk of major violence, ${ }^{52}$ then the analysis will tend to understate the UN's ability to prevent armed conflict.

Many of our control variables follow from Cunningham. ${ }^{53}$ We control for the number of SD movement factions (logged), which Cunningham shows to robustly increase the chance of civil war. Cunningham also finds that previous concessions play a role in the outbreak of violent conflict, and we include this measure to control for the history of conflict management between movements and governments. We include a binary indicator of democracy in the models, since democratic states have more legitimate political avenues by which the SD group's grievances can be heard, and therefore are less likely to experience civil war. ${ }^{54}$ The presence of ethnic kin groups in neighboring states has been shown to increase the propensity for armed conflict, and so we include a binary indicator of such groups. ${ }^{55}$ Gross domestic product (GDP) per capita has a robust correlation with intrastate conflict, ${ }^{56}$ as does the number of active SD groups. ${ }^{57}$ Finally, we control for the average amount of economic discrimination in the country from the Minorities at Risk data, since Cederman, Gleditsch and Buhaug find that discrimination in ethnic conflicts shapes the propensity for political violence. ${ }^{58}$

\footnotetext{
50 These are just the counts of the SD movements at risk of conflict with these types of resolutions at some point from 1960 to 2005. Since most of these movements experienced multiple resolutions during that time period, the number of relevant resolutions is much higher.

51 We use a four-year half-life in part because Beardsley (2008) finds that mediation no longer has a positive stabilizing effect after four years, due to the declining influence of the third parties involved. We also test and find that the key results are robust to a shorter half-life of two years.

52 Beardsley and Schmidt 2012.

53 Cunningham 2013.

54 E.g., Fearon and Laitin 2003; Hegre et al. 2001. Democracies are those with a Polity index greater than 6 (Marshall and Jaggers 2000).

55 Jenne 2007.

56 Collier and Hoeffler 2004; Fearon and Laitin 2003; Hegre and Sambanis 2006.

57 Walter 2006.

58 Cederman, Gleditsch, and Buhaug 2013.
} 
In addition to these core control variables, we conducted additional robustness checks by adding additional regional temporal control variables in order to account for other possible confounds. Specifically, we included dummy variables for sub-Saharan Africa, Asia and Eastern Europe ${ }^{59}$ as well as a dummy variable for the Cold War. The key results are robust to these extensions and are reported in the Appendix (Table A3). We also include in robustness models a measure of whether peacekeeping operations, from the International Military Interventions data, are deployed to the respective countries (Table A4). We do not include this as a core control variable because it is an intermediate variable between the force authorization measures and the outcomes of interest. That being said, it is telling that the findings are similar with and without this variable, which suggests that the effect of the force mandates does not solely operate through the deployment of troops on the ground, and that there is likely to be a broader signaling effect of strong UNSC action. Finally, we also considered the possibility that the estimated size of the group as a percentage of the state's population and the presence of hydrocarbon reserves might shape both regime-rebel incentives and the UNSC response. The results are robust to the inclusion of these variables, and they have little independent effect on the outcome (Table A5).

Table 2 presents the regression results for our models of the more active types of UN activity. Due to space constraints, the results for the more passive types of UN involvement condemnations and simple reauthorizations of force - are shown in the Appendix and indicate that such actions do not have a statistically significant relationship with the onset of conflict (Table A2). Our theoretical discussion highlighted the potential distinction between UNSC resolutions that directly and indirectly pertain to SD movements. We discuss the evidence for each of these mechanisms in sequence below. ${ }^{60}$

\section{RESULTS}

The results from the first two models show evidence of effective direct conflict management from diplomatic engagement. UNSC resolutions authorizing diplomacy directly related to the SD dispute are strongly associated with a decrease in the likelihood of armed conflict. The top panel in Figure 1 uses the results from the first model to show this relationship substantively. In expectation, periods immediately after UNSC resolutions that contain instructions for diplomatic measures (when the weight variable increases by 1) are about 60 per cent less likely to experience armed-conflict onset. The second model shows that the preventive role of diplomacy holds for cases in which the SD movement had never participated in a civil war. So, this finding is capturing prevention before violence erupts and not simply previous conflict management during a violent conflict that only delays the relapse of the same conflict.

Turning to the third through sixth columns, we do not find evidence of preventive conflict management for authorizations of new force or sanctions that directly pertain to the SD movements. The coefficient on the direct authorizations of new force variable is not statistically significant, while that on sanctions is positive and significant, meaning that civil war is more likely following UNSC authorizations of sanctions. ${ }^{61}$ One might suspect that this positive effect is evidence of a moral hazard effect in which sanctions embolden one side in the dispute.

\footnotetext{
${ }^{59}$ We include regional dummies in lieu of country fixed effects, because the inclusion of country fixed effects would exclude from the analysis all cases without armed conflict.

${ }^{60}$ Models that include direct and indirect UNSC activity separately have similar results. We present them in the online appendix (Tables A8 and A9).

61 The estimation in the model of first conflicts did not produce a coefficient for the direct sanctions measure because there were only two observations in which the direct-sanctions weight was non-zero for this subsample.
} 
TA в LE 2 Logit Models of Armed Conflict Onset

\begin{tabular}{|c|c|c|c|c|c|c|}
\hline & \multicolumn{2}{|c|}{ Diplomacy } & \multicolumn{2}{|c|}{ New force } & \multicolumn{2}{|c|}{ Sanctions } \\
\hline & All & First & All & First & All & First \\
\hline \multirow[t]{2}{*}{ Direct respective action } & $-1.358 * *$ & $-5.434 * *$ & 0.345 & -0.0148 & $2.756 * * *$ & \\
\hline & $(0.690)$ & $(2.165)$ & $(0.231)$ & $(0.405)$ & $(0.965)$ & \\
\hline \multirow{2}{*}{ Other direct actions } & $0.180 * *$ & $0.657 * * *$ & -0.0198 & $0.214^{*}$ & -0.0781 & 0.159 \\
\hline & $(0.0762)$ & $(0.185)$ & $(0.0223)$ & $(0.117)$ & $(0.0660)$ & $(0.123)$ \\
\hline \multirow[t]{2}{*}{ Indirect respective action } & 0.0723 & -1.552 & $-3.847 * *$ & $-4.477 *$ & $-0.411 * * *$ & -0.201 \\
\hline & $(0.496)$ & (1.014) & $(1.582)$ & $(2.638)$ & $(0.157)$ & $(0.301)$ \\
\hline \multirow[t]{2}{*}{ Other indirect actions } & -0.0616 & 0.149 & 0.00442 & 0.000328 & 0.0128 & -0.0193 \\
\hline & $(0.0866)$ & $(0.136)$ & $(0.0472)$ & $(0.0730)$ & $(0.0375)$ & $(0.0429)$ \\
\hline \multirow[t]{2}{*}{ Factions (logged) } & $1.030 * * *$ & $0.945 * * *$ & $0.957 * * *$ & $0.842 * * *$ & $1.037 * * *$ & $0.864 * * *$ \\
\hline & $(0.200)$ & $(0.267)$ & $(0.199)$ & $(0.272)$ & $(0.200)$ & $(0.261)$ \\
\hline \multirow[t]{2}{*}{ Previous concessions } & -0.283 & -0.587 & -0.253 & -0.622 & -0.258 & -0.598 \\
\hline & $(0.257)$ & $(0.426)$ & $(0.257)$ & $(0.425)$ & $(0.255)$ & $(0.442)$ \\
\hline \multirow[t]{2}{*}{ Democracy } & $-0.553 *$ & $-0.826^{* *}$ & $-0.523^{*}$ & $-0.782 * *$ & $-0.590 * *$ & $-0.761 * *$ \\
\hline & $(0.292)$ & $(0.382)$ & $(0.289)$ & $(0.376)$ & $(0.300)$ & $(0.380)$ \\
\hline \multirow[t]{2}{*}{ Neighboring kin groups } & $0.648 * *$ & 0.176 & $0.641^{* *}$ & 0.176 & $0.591 * *$ & 0.120 \\
\hline & $(0.260)$ & $(0.388)$ & $(0.258)$ & $(0.397)$ & $(0.269)$ & $(0.397)$ \\
\hline \multirow{2}{*}{ GDP per capita (logged) } & -0.143 & $-0.345^{*}$ & -0.158 & -0.295 & -0.140 & -0.307 \\
\hline & $(0.110)$ & $(0.195)$ & $(0.104)$ & $(0.198)$ & $(0.111)$ & $(0.201)$ \\
\hline \multirow[t]{2}{*}{ Number of groups } & $0.0788 * *$ & 0.0430 & $0.0823 * * *$ & 0.0503 & $0.0796 * *$ & 0.0448 \\
\hline & $(0.0320)$ & $(0.0398)$ & $(0.0314)$ & $(0.0392)$ & $(0.0337)$ & $(0.0404)$ \\
\hline \multirow[t]{2}{*}{ Economic discrimination } & 0.0427 & 0.0154 & 0.0429 & 0.0110 & 0.0424 & 0.0135 \\
\hline & $(0.0899)$ & $(0.156)$ & $(0.0882)$ & $(0.154)$ & $(0.0915)$ & $(0.156)$ \\
\hline \multirow[t]{2}{*}{ Risk time } & $-0.378 * * *$ & $-0.387 * * *$ & $-0.368 * * *$ & $-0.365 * * *$ & $-0.361 * * *$ & $-0.327 * * *$ \\
\hline & $(0.0645)$ & $(0.107)$ & $(0.0629)$ & $(0.104)$ & $(0.0653)$ & $(0.102)$ \\
\hline \multirow[t]{2}{*}{ Constant } & $-2.365 * *$ & -0.321 & $-2.230 * *$ & -0.657 & $-2.409 * *$ & -0.681 \\
\hline & (0.979) & (1.738) & $(0.935)$ & (1.756) & $(1.011)$ & (1.778) \\
\hline Observations & 2,334 & 1,869 & 2,334 & 1,869 & 2,334 & 1,867 \\
\hline
\end{tabular}

Note: robust standard errors in parentheses. Squared and cubed risk time not shown (see Appendix Table A6). ***p $<0.01,{ }^{* *} \mathrm{p}<0.05,{ }^{*} \mathrm{p}<0.10$, two-tailed test.

However, the observation that the relationship involving indirect sanctions (discussed below) is opposite that involving direct sanctions casts doubt on this interpretation because both direct and indirect sanctions tend to target the governments and should have similar effects if a moral hazard mechanism dominated. It is also possible that this positive correlation occurs because the UNSC is more likely to impose sanctions in disputes that are escalating to civil war, and thus the likelihood of civil war causes the UNSC resolution, and not the other way around. Moreover, it makes sense that this selection effect would be stronger for the directly pertinent sanctions because of the greater incentives to avoid ambiguity when the situation is dire. Below we discuss alternative approaches that help identify the causal direction and mitigate this possible source of endogeneity bias.

Examining the effects of UNSC resolutions that indirectly pertain to the SD movements, we find that indirect authorizations of new force and sanctions are associated with a decrease in the likelihood of civil war. The bottom panels in Figure 1 show these relationships, as well as how the authorization of force has a much stronger substantive effect than sanction declarations. Recent indirectly pertinent resolutions that authorize force almost completely eliminate the likelihood of armed-conflict onset, while indirectly pertinent resolutions that authorize sanctions decrease that likelihood by about 40 per cent in expectation. It appears that more heavy-handed UN action authorized in a broader regional context can have strong indirect deterrent effects 

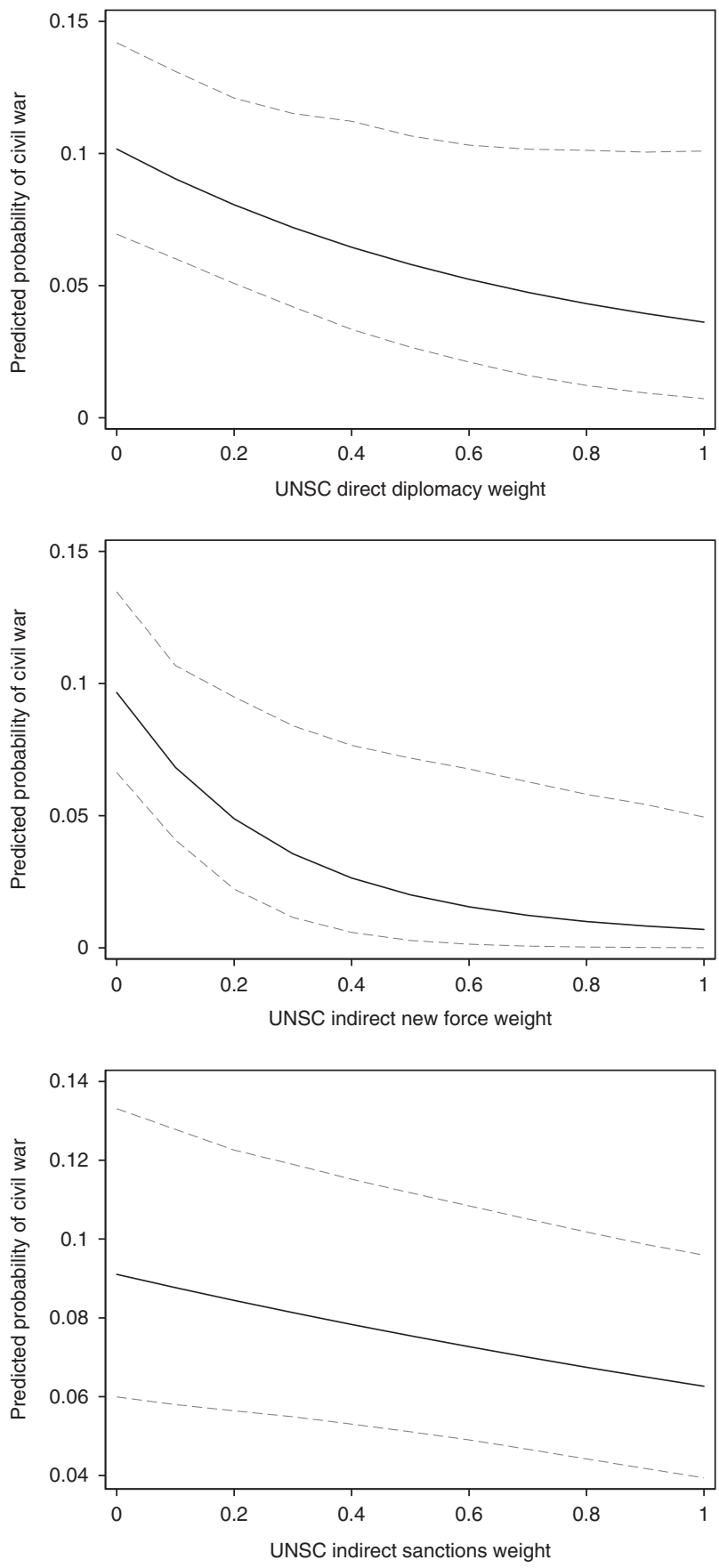

Fig. 1. Marginal effects of types of UNSC resolutions, with 95\% confidence intervals

where the deployment of military personnel and the authorization of sanctions can increase the current or expected opportunity costs of escalating to violence. We note that less substantive types of UNSC actions, such as diplomatic engagement and condemnations, do not have 
preventive effects on SD movements that are only indirectly relevant to the resolutions, which is expected from actions that do not have wider implications for the actors' cost-benefit assessments. We also note that the observed deterrent effect of indirectly pertinent new authorizations of force is even robust to when the sample only includes movements that have never experienced a civil war, while indirectly pertinent authorizations of sanctions are not.

These findings on indirectly related UNSC activity are particularly striking given the implausibility that they can be explained by endogeneity bias. If the UN were to cherry-pick easy cases for intervention, we would expect this tendency to be much stronger for directly relevant actions than for indirectly relevant resolutions. We doubt that the UNSC would benefit much from leaving ambiguous the application to easier SD disputes, such that it would not be able to take credit for successful prevention. The incentives to cherry-pick the easier cases would seem to be greater for directly pertinent UNSC actions, and yet such direct activity is not associated with conflict prevention (as indirect activity is).

The control variables included in the analyses in Table 2 reveal some interesting patterns. Consistent with Cunningham, armed conflict is much more likely in years in which SD movements have more factions. ${ }^{62}$ Democracies are less likely to experience civil war onsets, as are countries with higher average incomes, although the effect of GDP per capita is only statistically significant in one model. Consistent with Jenne and Walter, neighboring kin groups and a greater number of SD groups in the state make civil war more likely, but these effects are only significant in the full sample of SD dispute years. ${ }^{63}$ Longer periods of peace make civil wars less likely. Both previous concessions and economic discrimination have the expected signs (negative and positive, respectively), but neither is statistically significant. The finding on economic discrimination is somewhat surprising, but this is a countrywide measure of discrimination and so may not be a great measure of group-level discrimination. Additionally, the analysis by Cederman, Gleditsch and Buhaug showing that economic discrimination makes civil war more likely focuses on ethnic groups broadly, ${ }^{64}$ and we are focused on a subset of cases in which ethnic groups make a demand for greater local control; economic discrimination may make these disputes more likely to emerge in the first place.

\section{FURTHER ANALYSES}

While the observed deterrent effects of indirectly relevant authorizations of new force and sanctions are not likely to be explained by selection effects, the findings related to direct diplomacy and direct sanctions warrant additional scrutiny. If the process by which the UN chooses to directly act is related to the likelihood of civil war, then our results may be biased. Consider two possibilities: if the UN chooses to become involved in the easiest disputes - those in which the likelihood of civil war is the lowest - then the negative correlation between direct diplomacy and civil war may just indicate that these disputes were unlikely to escalate to civil war anyway, not that diplomacy has any effect. Yet if the UN chooses to become involved in the disputes with the highest likelihood of civil war, than a positive correlation between direct sanctions and civil war may simply indicate that sanctions are used in the most severe disputes, not that they increase the likelihood of civil war on their own. ${ }^{65}$ Empirically, in examining how

62 Cunningham 2013.

63 Jenne 2007; Walter 2006.

${ }^{64}$ Cederman, Gleditsch, and Buhaug 2013.

${ }^{65}$ For consideration of similar issues of selection effects related to peacekeeping, see Fortna $(2004,2008)$. Gartner (2011) and Beber (2012) discuss selection effects in the study of mediation. 
our control variables correlate with the types of intervention, we do not observe that diplomacy with direct relevance to an SD movement tends to be applied to the easier cases, or that sanctions with direct relevance tend to go to the more difficult cases. ${ }^{66}$

To further analyze the direct effects of diplomatic involvement and sanctions, we also conducted seemingly unrelated regression models to simultaneously estimate an equation of these types of direct UN involvement and the outcome equation while controlling for the correlation in errors between the equations. ${ }^{67}$ In doing so, we control for some of the processes left outside the model that potentially shape both how active the UN is in addressing an SD dispute and the ultimate potential for violence to escalate. We used dummies for the Cold War, Western states, P-5 status and P-5 allies as variables in the UN-involvement equation that did not appear in the outcome equations. ${ }^{68}$ These dummy variables are likely to affect the political feasibility of UNSC action ${ }^{69}$ without strong theoretical connections with the escalation of violence related to an SD movement.

In these regressions (Table A7), the correlations in the errors across the equations are not statistically significant, and the estimated relationships between conflict onset and both direct diplomatic activity and direct sanctions remain statistically significant. We therefore rely on the logit models in Table 2 for our analyses. The robustness of the finding that direct sanctions are associated with a higher likelihood of civil war remains puzzling, given that a moral hazard explanation is difficult to justify in light of the observation that indirect sanctions do not have a similar relationship with civil war onset. Further exploration reveals that four of the five cases of civil war onset when the UNSC has authorized sanctions in the recent past come from the Balkans. While the failure of the sanctions regime in the former Yugoslavia is well documented, ${ }^{70}$ we hesitate to generalize too much from what is essentially a single case.

\section{CONCLUSION}

This article provides strong evidence that UNSC involvement can substantially dampen the propensity for disputes between SD movements and their respective governments to escalate to civil war. We find robust support for the direct preventive effect of UNSC resolutions related to diplomatic activity. UN-led diplomacy can go a long way toward keeping SD movements from engaging in violent conflict. We also find robust support for the ability of military force and sanctions to indirectly deter other SD movements from turning violent.

We do not see any evidence that these relationships are driven by the non-random adoption of UNSC resolutions. The findings regarding UNSC resolutions' indirect effects are particularly noteworthy, because it is especially difficult to form a story for there being spurious indirect

\footnotetext{
66 As seen in the Appendix (Figure A1), we compared the means of the control variables during the years in which there was a resolution of each type to years in which there were no resolutions with that type of action. It is also noteworthy that there is a consistent pattern for the indirect types of actions, which tend to be associated with more difficult SD disputes that should have a higher likelihood of civil war onset. Accordingly, it is important to emphasize again that the findings with regard to the indirect actions are thus especially robust to critiques that any observed effects are the result of the non-random assignment of UN actions.

67 Each equation was estimated with ordinary least squares, so the outcome equations were linear probability models. Since we are specifically concerned about endogeneity related to the direct actions, we simplify the equations slightly by removing the indirect actions. We focus this robustness check on the prevention of new conflict because this is the hardest test for our preventive claims.

${ }^{68}$ All the variables in the selection (first) equation are lagged by one year, since the endogenous variable is the lagged UNSC activity.

69 Beardsley and Schmidt 2012.

70 E.g., Rieff 1996, 27-8.
} 
effects - if the UNSC were to cherry-pick cases for intervention, we would expect it to do so more in its direct actions. With the findings regarding the indirect ameliorative effect of both sanctions and force, we observe positive externalities to UN action. The policy implications are clear: we cannot judge the efficacy of UN action vis-à-vis SD disputes solely on the basis of the specific dispute at which the UN action was directed, but we should also take into account the broader regional environments that the UNSC often tries to stabilize.

We find strong evidence that the UNSC can have an important role in reducing the likelihood that SD disputes escalate to civil war, but there are clear avenues for future research. Future analysis may be able to examine when and how actions by other IGOs combine to affect the likelihood of civil war in SD disputes. UNSC resolutions often occur concurrently with actions by like-minded regional and international security organizations - for example, UNSC resolutions pertaining to the Balkans and Sudan have often accompanied military action by NATO and the African Union, respectively. While some additional robustness checks control for non-UN and UN peacekeeping missions, more could be done to unpack the role of non-UN actors.

Future study should also consider the preventive effects of UNSC action in non-SD disputes. While SD disputes are the underlying cause of the majority of civil wars in the past two decades ${ }^{71}$ there is an important class of civil wars that stem from disputes over the nature and composition of governments - separate from the grievances of SD groups. Indeed, many of the civil wars that currently receive considerable attention from international actions - such as those in Syria, Somalia and Iraq - are not, or at least not only, territorial conflicts. We focus on SD disputes here because doing so allows us to examine a clear set of potential civil wars. Theoretically, we would expect UNSC action to have similar effects in other disputes, because the UN still has the ability to take actions that affect the cost-benefit calculations of the actors and reduce barriers to potential settlements. However, it is also likely that the UN may respond differently to these different types of conflict. It is possible that the UN is more active in SD disputes because they have the potential to lead to the break-up of states and thus threaten the international order. As such, there may be broader agreement among the P-5 members about how to respond to these disputes than to disputes about the composition of a country's government. Future research should seek to identify a set of non-violent disputes over government that have the potential to escalate to civil war and examine whether the UN and other international actors act in ways in these disputes that reduce the risk of civil war.

\section{REFERENCES}

Ackermann, Alice, and Antonio Pala. 1996. From Peacekeeping to Preventive Deployment: A Study of the United Nations in the Former Yugoslav Republic of Macedonia. European Security 5 (1):83-97.

Beardsley, Kyle. 2008. Agreement without Peace? International Mediation and Time-Inconsistency Problems. American Journal of Political Science 42 (4):723-40.

—. 2011. Peacekeeping and the Contagion of Armed Conflict. Journal of Politics 73 (4):1051-64.

- 2013. The UN at the Peacemaking-Peacebuilding Nexus. Conflict Management and Peace Science 30 (4):369-86.

Beardsley, Kyle, and Holger Schmidt. 2012. Following the Flag or Following the Charter? Examining the Determinants of UN Involvement in International Crises, 1945-2002. International Studies Quarterly 56 (1):33-49.

Beardsley, Kyle, and Kristian Skrede Gleditsch. 2015. Peacekeeping as Conflict Containment. International Studies Review 17 (1):67-89.

${ }^{71}$ Cunningham 2013, 659. 
Beardsley, Kyle, and Nigel Lo. 2013. Third-party Conflict Management and the Willingness to Make Concessions. Journal of Conflict Resolution 58 (2):363-92.

Beber, Bernd. 2012. International Mediation, Selection Effects, and the Question of Bias. Conflict Management and Peace Science 29 (4):397-424.

Beck, Nathaniel, Jonathan N. Katz, and Richard Tucker. 1998. Taking Time Seriously: Time-series-crosssection Analysis with a Binary Dependent Variable. American Journal of Political Science 42 (4): 1260-88.

Benson, Michelle A., and Jacob Kathman. 2014. UN Bias and Force Commitments in Civil Conflicts. Journal of Politics 76 (2):350-63.

Bercovitch, Jacob, and Scott Sigmund Gartner, eds. 2008. International Conflict Mediation: New Approaches and Findings. London: Routledge.

Carter, David B., and Curtis S. Signorino. 2010. Back to the Future: Modeling Time Dependence in Binary Data. Political Analysis 18 (3):271-92.

2013. Good Times, Bad Times: Left-Censoring in Grouped Binary Duration Data. Presented at the 2013 meeting of the International Studies Association, 3-6 April, San Francisco, CA.

Cederman, Lars-Erik, Kristian Skrede Gleditsch, and Havard Buhaug. 2013. Inequality, Grievance and Civil War. London: Cambridge University Press.

Chapman, Terrence L. 2009. Audience Beliefs and International Organization Legitimacy. International Organization 63 (4):733-64.

Collier, Paul, and Anke Hoeffler. 2004. Greed and Grievance in Civil War. Oxford Economic Papers 56 (4):563-95.

Cunningham, Kathleen Gallagher. 2013. Actor Fragmentation and Civil War Bargaining: How Internal Divisions Generate Civil Conflict. American Journal of Political Science 57 (3):659-72.

DeRouen, Jr., Karl, and Frida Möller. 2013. The Short-term Effects of Mediation on Low-Intensity Civil Wars. Negotiation Journal 29 (4):413-37.

Diehl, Paul F., Jennifer Reifschneider, and Paul R. Hensel. 1996. United Nations Intervention and Recurring Conflict. International Organization 50 (4):683-700.

Doyle, Michael W., and Nicholas Sambanis. 2000. International Peacebuilding: A Theoretical and Quantitative Analysis. American Political Science Review 94 (4):779-801.

Drezner, Daniel W. 2003. The Hidden Hand of Economic Coercion. International Organization 57 (3):643-59.

Elliott, Kimberly Ann. 1998. The Sanctions Glass: Half Full or Completely Empty? International Security 23 (1):50-65.

Escribà-Folch, Abel. 2012. Authoritarian Responses to Foreign Pressure Spending, Repression, and Sanctions. Comparative Political Studies 45 (6):683-713.

Fearon, James D. 1995. Rationalist Explanations for War. International Organization 49:379-414.

Fearon, James D., and David D. Laitin. 2003. Ethnicity, Insurgency, and Civil War. American Political Science Review 97 (1):75-90.

Fey, Mark, and Kristopher Ramsay. 2010. When is Shuttle Diplomacy Worth the Commute? Information Sharing through Mediation. World Politics 62 (4):529-60.

Fortna, Virginia Page. 2004. Does Peacekeeping Keep Peace? International Intervention and the Duration of Peace after Civil War. International Studies Quarterly 48 (2):269-92.

2008. Does Peacekeeping Work?: Shaping Belligerents' Choices After Civil War. Princeton, NJ: Princeton University Press.

Francisco, Ronald A. 1995. The Relationship between Coercion and Protest: An Empirical Evaluation in Three Coercive States. Journal of Conflict Resolution 39 (2):263-82.

Gartner, Scott Sigmund. 2011. Signs of Trouble: Regional Organization Mediation and Civil War Agreement Durability. The Journal of Politics 73 (2):380-90.

Gent, Stephen E., and Megan Shannon. 2010. The Effectiveness of International Arbitration and Adjudication: Getting into a Bind. The Journal of Politics 72 (2):366-80.

Gleditsch, Nils Petter, Peter Wallensteen, Mikael Eriksson, Margareta Sollenberg, and Håvard Strand. 2002. Armed Conflict 1946-2001: A New Dataset. Journal of Peace Research 39 (5):615-37. 
Greig, J. Michael, and Paul F. Diehl. 2005. The Peacekeeping-Peacemaking Dilemma. International Studies Quarterly 49 (4):621-46.

Hegre, Håvard, and Nicholas Sambanis. 2006. Sensitivity Analysis of Empirical Results on Civil War Onset. Journal of Conflict Resolution 50 (4):508-35.

Hegre, Håvard, Tanja Ellingsen, Scott Gates, and Nils Petter Gleditsch. 2001. Toward a Democratic Civil Peace? Democracy, Political Change, and Civil War, 1816-1992. American Political Science Review 95 (1):33-48.

Hultman, Lisa, Jacob Kathman, and Megan Shannon. 2013. United Nations Peacekeeping and Civilian Protection in Civil War. American Journal of Political Science 57 (4):875-91.

Jenne, Erin K. 2007. Ethnic Bargaining: The Paradox of Minority Empowerment. Ithaca, NY: Cornell University Press.

Karreth, Johannes, and Jaroslav Tir. 2013. International Institutions and Civil War Prevention. Journal of Politics 75 (1):96-109.

Kuperman, Alan J. 2005. Suicidal Rebellions and the Moral Hazard of Humanitarian Intervention. Ethnopolitics 4 (2):149-73.

Kydd, Andrew. 2003. Which Side Are You On? Bias, Credibility, and Mediation. American Journal of Political Science 47 (4):597-611.

Kydd, Andrew H. 2006. When Can Mediators Build Trust? American Political Science Review 100 (3):449-62.

Kydd, Andrew H., and Barbara F. Walter. 2006. The Strategies of Terrorism. International Security 31 (1):49-80.

Lichbach, Mark Irving. 1998. The Rebel's Dilemma. Ann Arbor: University of Michigan Press.

Marinov, Nikolay. 2005. Do Economic Sanctions Destabilize Country Leaders? American Journal of Political Science 49 (3):564-76.

Marshall, Monty G., and Keith Jaggers. 2000. Polity IV Project. Available from http://www.systemicpeace. org/polityproject.html, accessed 2 April 2015.

Marshall, Monty G., and Ted Robert Gurr. 2003. Peace and Conflict 2003: A Global Survey of Armed Conflicts, Self-Determination Movements, and Democracy. College Park, MD: Center for International Development and Conflict Management.

Mikulaschek, Christoph, and Chris Perry. 2013. When Do Civil-War Parties Heed the UN? Findings from the IPI Security Council Compliance Database. New York: IPI.

Minorities at Risk Project (MAR). 2009. Minority Group Chronologies. Minorities at Risk Dataset. College Park, MD: Center for International Development and Conflict Management. Available from http://www.cidcm.umd.edu/mar/, accessed 12 June 2013.

Moore, Will H. 1998. Repression and Dissent: Substitution, Context, and Timing. American Journal of Political Science 42 (3):851-73.

Pape, Robert. 1997. Why Sanctions Do Not Work. International Security 22 (2):90-136.

Powell, Robert. 2006. War as a Commitment Problem. International Organization 60 (1):169-203.

Rieff, David. 1996. Slaughterhouse: Bosnia and the Failure of the West. New York: Simon and Schuster.

Quinn, David, Jonathan Wilkenfeld, Pelin Eralp, Victor Asal, and Theodore Mclauchlin. 2013. Crisis Managers but not Conflict Resolvers: Mediating Ethnic Intrastate Conflict in Africa. Conflict Management and Peace Science 30 (4):387-406.

Rauchhaus, Robert W. 2009. Principal-Agent Problems in Humanitarian Intervention: Moral Hazards, Adverse Selection, and the Commitment Dilemma. Journal of Conflict Resolution 53 (4):871-84.

Regan, Patrick M., and Aysegul Aydin. 2006. Diplomacy and other forms of Intervention in Civil Wars. Journal of Conflict Resolution 50 (5):736-56.

Sambanis, Nicholas. 1999. The United Nations Operation in Cyprus: A New Look at the PeacekeepingPeacemaking Relationship. International Peacekeeping 6 (1):79-108.

Smith, Alastair, and Allan Stam. 2003. Mediation and Peacekeeping in a Random Walk Model of Civil and Interstate War. International Studies Review 5 (4):115-35.

Themnér, Lotta, and Peter Wallensteen. 2012. Armed Conflicts, 1946-2011. Journal of Peace Research 49 (4):565-75. 
Thompson, Alexander. 2009. Channels of Power: The UN Security Council and U.S. Statecraft in Iraq. Ithaca, NY: Cornell University Press.

Toft, Monica Duffy. 2006. Issue Indivisibility and Time Horizons as Rationalist Explanations for War. Security Studies 15 (1):34-69.

Voeten, Erik. 2005. The Political Origins of the UN Security Council's Ability to Legitimize the Use of Force. International Organization 59 (3):527-57.

Walter, Barbara F. 2002. Committing to Peace: The Successful Settlement of Civil Wars. Princeton, NJ: Princeton University Press.

- 2006. Building Reputation: Why Governments Fight some Separatists but not Others. American Journal of Political Science 50 (2):313-30.

2009. Bargaining Failures and Civil War. Annual Review of Political Science 12:243-61.

Wood, Reed M. 2008. 'A Hand upon the Throat of the Nation': Economic Sanctions and State Repression, 1976-2001. International Studies Quarterly 52 (3):489-13. 